\title{
Leontiev about Matter and Consciousness: His Critique of Vygotsky in the Soviet context
}

\author{
Gisele Toassa (1) \\ Universidade Federal de Goiás, Goiânia, GO, Brasil
}

\begin{abstract}
Closing out a set of six articles, this text presents a descriptive analysis of Leontiev's career between 19367 in the context of the profound changes caused by the Decree against Pedology and subsequent public campaign against the Vygotskian legacy. This paper seeks to outline the meaning of this campaign within the sinister context of the Soviet Great Purge and place Leontiev's main critical text of Vygotsky in the context of the enforcement of a "pure and genuine" Marxism-Leninism on the sciences. We claim that Leontiev confused the ontological and epistemological problem of the relationship of consciousness to matter, reflecting the Stalinist divisions between them. When Leontiev moved away from Vygotsky’s legacy, he pursued a dualist, objectivist, and mechanistic inflection of Vygotsky’s psychological materialism.
\end{abstract}

KEYWORDS: activity theory, Leontiev, Vygotsky, CHAT, Soviet Union

\section{Leontiev sobre Matéria e Consciência: Sua Crítica a Vigotski nos Anos 1930s*}

\begin{abstract}
RESUMO - Completando um ciclo de seis artigos, este texto apresenta análise descritiva da carreira de Leontiev entre 1936-7, no contexto das profundas transformações causadas pelo Decreto contra a Pedologia de 1936 e subsequente campanha pública contra o legado vigotskiano. Procura delinear o sentido dessa campanha na sinistra conjuntura dos Grandes Expurgos stalinistas e situar o principal texto de crítica de Leontiev a Vigotski. Trata de mudanças teóricas nas obras dos autores em relação com a imposição de um "puro e genuíno" marxismo-leninismo às ciências. Defendo que Leontiev confundiu o problema ontológico e epistemológico sobre a relação consciência-matéria, repercutindo as cisões stalinistas entre ambas. Ao afastar-se do legado de Vigotski, realizou uma inflexão dualista, objetivista e mecanicista no materialismo psicológico vigotskiano.
\end{abstract}

PALAVRAS-CHAVE: teoria da atividade, Leontiev, Vigotski, psicologia histórico-cultural, União Soviética

\section{REQUIEM}

1935-1940

No, and not under an alien sky,

And not under the protection of alien wings -

I was with my people then

Where my people, unfortunately, were.

(Anna Akhmatova, 1961, p.89)

In our post-doctoral research dedicated to the conceptual field of psychic synthesis in Leontiev's psychology, this article is part of a series of four works published in Brazilian periodicals/books and two in Russian periodicals with
Portuguese-language versions (following a logical sequence of problematization: Toassa, 2015a, 2015b, 2017, 2016a, $2016 b$ ). Rounding out the arc of these first studies, this paper continues the analysis of critical points made by Aleksei Nikolaevich Leontiev (1903-1979, hereafter referred to as A.N.), a researcher in Vygotskian circles, regarding the work of Vygotsky.

Leontiev's work has been known in Brazil since approximately the second half of the 1970s (see Freitas, 1994), and the popularity of his work has only grown in recent decades, thanks especially to the boost that was provided by the research carried out by educator Newton

\footnotetext{
* Apoio: Capes

** E-mail: gtoassa@gmail.com

- Submetido: 13/01/2015; Revisado: 03/04/2018; Aceito: 07/08/2018.
} 
Duarte (1996, 2001), who argued for a Marxist reading of Vygotsky through a comparison with Leontiev and other Soviet writers. This reading of Duarte relies on the so-called "hagiographical narrative" that was carried out by Leontiev's son, Aleksei Alekseievich (hereafter referred to as A.A.) in 1983 (see Yasnitksy, 2009). Based specifically on oral reports obtained in the 1970s - the decade during which Luria and Leontiev died, and which saw many homages to the authors - one of its central elements is the notion that a historical-cultural psychology was developed by the troika of Vygotsky, Luria, and Leontiev. In this understanding, Leontiev's activity theory represents an evolution of the initial theorizing provided by Vygotsky and Luria.

However, in Brazil there has been a significant mismatch between publications in English and Russian in recent years, ranging from oral histories to research in archives of the former Soviet Union. This also applies to institutions where Vygotskians work, with a radical revision underway of the history of Vygotskian psychology (see Yasnitsky, 2012). Unfortunately, we have limited access to this work in Portuguese, as well as to important texts and commentaries made by A.N. about not only the context in which he lived but also about Vygotsky's concepts. With the exception of works by Martins (2013a, b), we have no output from critical Brazilian psychology about this vital historical revisionism.

As for the USSR, the paradigm of an "innocent historiography" of ideas has shown itself to be extremely deficient; this view affirms with vigor the Marxian imperative that science must move from the appearance to the essence of facts. Seeking out a totalizing analysis of the historical-theoretical relationship, this article focuses on the content of the text "Study of the Environment in the Pedological Works of LS Vygotsky" (193?/2005c). Other materials from the 1940s will also be used - especially as they concern the notion of consciousness, matter, and their relationships to language. Working within a context marked by the worst years of the Stalinist dictatorship, we seek to show how Leontiev, in his criticism of Vygotsky, shifts towards the Marxist-Leninist doctrine of Stalin (Netto, 1982). The context for the development of this latter doctrine takes place after the extinguishing of pedology through the decree "On pedological distortions in the Narkompros system" (1936) and its possible impact on Leontiev's career in 1936-7.

In explaining this process, we will present the direct and/ or indirect conceptual links between the texts of A.N. and the decree against pedology, as well as excerpts from Stalin's own writing that deal with materialism. In this zeitgeist, traces of Soviet Lamarckism can also be seen in the "Study of the Environment..." as well as in other texts by Leontiev from around the same time.

These aspects seek to develop elements inserted in the second article of the series in Portuguese, focused on Leontiev's career and some of his criticisms of Vygotsky. In that text, we concluded that, based on the critiques of "linguocentrism" of Vygotsky himself, carried out alongside with other members of the Kharkov Circle, Leontiev created a form of Marxism that sought to locate "objective reality" itself in the idea of "activity". This operation eliminated the need for mediation by theoretical ideas about consciousness as developed by Vyogotsky, using Stalinist methods (see Toassa, 2016a, b).

With this text we also seek to close out our discussion of the effects of Stalinist criticisms of Vygotsky using the work of his old disciple. Our effort at substantiating this analysis was born out of the commitment to seek out a Latin American Vygotskian psychology soaked in socialist ethics and willing to serve the creation of new theoretical syntheses implicated in the full emancipation of our oppressed peoples.

\section{IN SEARCH OF A “PURE AND GENUINE” MARXISM}

By encouraging competition for a "genuine Marxism," the monolithic rationale of Stalin and his bureaucrats followed a logic of divide and conquer, accompanying the activities of different groups working within psychology almost all of them seeking to become viable as bearers of the "true" Marxist psychology - to then decide in favor of one of them (see Yasnitsky \& Ferrari, 2008b, p. 114). This was common in scientific production under Stalin (1929-1953), as noted by Krementsov (1997).

One of the most authoritarian facets of Stalinist authoritarianism consisted of the promotion of official doctrines in all fields of culture, where "those who don't fit in [...] are expelled in the name of "purity" (Netto, 1982, p. 31). For Bauer (1952, p. 128) the publication of the second edition of the "Foundations of General Psychology" by Rubinstein in 1940, which was awarded the Stalin Prize in 1942, marked the definition of a new theoretical line that evolved out of the 1936 decree. Joravsky (1989, p. 372) argues that during the 1930s and 1940s Rubsinstein was the one who advocated the most strongly for the correct line to be followed by psychology - which led to his being labeled a Stalinist, due in part to some antipathy from Vygostky's former pupils and their own self-image as the legitimate heirs of the leadership of Soviet psychology. The article published by Rubinstein in 1934 (see Rubinštejn, 1987) was a watershed moment that marked the promotion of the category of activity to the central plane of psychological science, as recognized by A.N. Leontiev himself (1978a, b).

The date of Leontiev's writing (193?/2005) cannot be positively determined. Leontiev, Leontiev \& Sokolova (2005) indicate that it was written approximately in 1937; Yasnitsky (2009) says sometime around 1936 or 1937. If it was written in 1936, it would come after the decree against 
pedology but before the official campaign of criticism against Vygotsky.

The text possibly served as the basis for an oral presentation by Leontiev. According to Yasnitsky, it was found in the archives of the Psychology Institute (of Moscow) but was not included by A.N. Leontiev in his own bibliography (see Leontiev et al., 2005). Its authorship, however, was recognized and commented on by the author's family.

Given the circumstances that surround the writing of the text, we think that many readers could feel compelled to discard it as the mere fulfilment of a political ritual, devoid of any theoretical value. However, as far as Soviet authoritarianism is concerned, it seems obvious to us that this line of historical interpretation has become sterile (see Toassa, 2016), especially considering that the text is not lacking in resonance with other works by Leontiev. In it, important differences with Vygotsky are expounded with clarity.

Nevertheless, A.N. Leontiev's criticism shows traces of so-called doublespeak, as identified by Yasnitsky (2009) in materials dating from the same year: a discourse with purposeful inversions of the affirmations of the critiqued work, seeking to please censors while at the same time making his ideas understandable to an audience of initiates. Aware of this aspect, we will set aside the conceptual mistakes present in Leontiev (193?/2005c) when commenting on Vygotsky.

\section{PEDOLOGY AND ITS EXTINCTION}

The meaning of the term "pedology" has become increasingly familiar in Brazil (see Vygotsky, 2010, and commentary texts in the "Vygotsky Dossier" published in this same issue of Psicologia USP), although discussions about Leontiev's relationship to this science or its elimination are nonexistent. Vygotsky (according to van der Veer \& Valsiner, 2001) saw in pedology a synthesis of various disciplines of childhood studies - bringing together the study of education and childhood development, while pathologies and special education were the task of defectology. Vygotsky was one of pedology's main proponents, along with Basov, Blonsky, and Nechayev.

When the "On pedological distortions in the Narkompros system" decree was published in Pravda in July 4, 1936, many of Vygotsky's former collaborators (not Leontiev) continued to practice pedology (see Toassa, 2016b). Spanning four pages, the decree consisted of a preamble with some considerations regarding critiques of pedology, concluding that

The methods of the pedologists sought to prove, from a 'scientific' and 'biosocial' point of view of contemporary pedology, the hereditary and social conditionality of the poor performance of students or of some defects in their behavior, as well as finding the maximum negative influences and pathological disorders in the student, their family, relatives, antecedents, and social environment, and as a result find reasons for the expulsion of students from the normal educational collective. (Central Committee of the RCP(b) 1936/2011, p. 206)

This preamble was followed by eight obligatory statements that decided, among other measures, to do away with the presence of pedologists in schools and to confiscate pedology books. In a bolshevizing language of war, fitting for the 1930s, special schools are accused of being responsible for the bad behaviors and tendencies of children registered therein, transforming them into children "who are difficult to correct" (Central Committee of the RCP(b) 1936/2011, p. 207).

Promulgated during the first year of the great Stalinist purges (1936-1939), it created an atmosphere of panic and confusion. Following Ellenstein, Netto (1982) notes that the old guard of the Party was eliminated. It has been estimated that the political police arrested "more than 5 million people and executed one tenth of this number" (Netto, 1982, p. 18). Another movement had been unleashed that radically reconfigured institutions and encouraged opportunism by groups of scientistsbureaucrats linked to the Party (Krementsov, 1997), as well as moving examples of mutual aid between scientists, be they residents of the Soviet Union or not (as was the case of Leon Orbeli, Nikolai Vavilov, and Theodosius Dobzhansky, according to Krementsov, 1997). This was a period of growing criticism aimed at condemning rival scientists, with an accompanying search for job postings at the cost of firings, imprisonment, or even the death of rivals, sometimes irreversible - even following autocriticism and appeals by the attacked to decision makers within the Party. At this point, the first moment of vehement persecution of geneticists by Lysenko and his allies was already taking place, leading to the imprisonment (and subsequent death in prison) of the renowned Nikolai Vavilov, who was accused of treason (Krementsov, 1997, pp. 78-79).

\section{AND LEONTIEV? WHAT WAS HE DOING IN 1936-7?}

A public campaign to criticize Vygotsky began with the publication of thousands of copies of the infamous Rudneva
(1937/2005) pamphlet, whose content was analyzed previously (Toassa, 2016a). 
Leontiev's work situation between 1936 and 1937 is difficult to determine. We found three versions: the first, by Golder (2004), says that A.N. had become a psychology professor at Moscow State University in 1936, at the same time sharing with Elkonin the chair of the psychology department at the Leningrad Pedagogical Institute. However, the latter told Vygodskaya (Vygodskaya \& Lifanova, 1999) that he was fired after the decree against pedology was published, and was unemployed for several years as a result of his refusal to engage in self-criticism, and thereby defending the Vygostkian legacy.

A second version is provided by the Leontiev family (Leontiev et al., 2005, p.18) which mentions the closing of the Higher Communist Institute of Pedagogy (VKIP) in Moscow (1937) where he did his research. Aleksei Nikolaevich described the transfer of the lab to the Teaching Methods Institute (A.A. Leontiev, 2005), with some records of his being included on the payroll. Admitting that he was not personally attacked, they note: A.N. was out of work until the fall of 1937, when K.N. Kornilov was once again named director of the old Psychology Institute, hiring him as a researcher in strictly applied fields (Leontiev et al., 2005). At the same time, he began to give lectures and study artistic perception at the All-Union State Institute of Cinematography and the State Institute of Theater Arts (A.A. Leontiev, 2005). Although A.N. sought to explain his critique of Vygotsky as necessary for survival, the family finally says that Leontiev (193?/2005c) presents "already established theoretical discrepancies between Vygotsky and the Kharkov group" (Leontiev et al., 2005, p.19, our translation), something which we confirmed in previous articles in this series (Toassa, 2016a).

The third version, by Yasnitsky (2009) notes, based on archival records, that Leontiev continued to travel occasionally to Kharkov, being formally employed by the Institute of Psychoneurology until December 1936, and by the State Pedagogical Institute of Kharkov until December 1937. During the second half of the 1930s he had begun to commute between Kharkov, Moscow, and Leningrad, completing his doctoral thesis in 1939 and defending it in Leningrad in 1940 (Yasnitsky \& Ferrari, 2008b). Yasnitsky (2009) says Leontiev was added to the rolls of the Herzen Pedagogical Institute only in 1939.

If the information from Yasnitsky and Golder do not seem to be incompatible - since it was common to hold several job postings simultaneously - Leontiev, Leontiev and Sokolova (2005) differ from the others in stating that Leontiev was out of work during part of 1937. Had the records of the institutional links he maintained been merely formal?

We have, therefore, only vague ideas about the impact that the general political situation had on the particular institutional setting in which his critique of Vygotsky was written. However, his work situation may have become more complicated, especially after the publication of Rudneva's critique (1937, which cites Leontiev among former disciples) and the public condemnation of Vygotsky. Serious sanctions such as threats of imprisonment, forced labor, or death - seem unlikely, as they applied to scientists with numerous foreign connections (as was the case of N. Vavilov), Trotskyists in general, individuals affiliated with the Party, or persons such as the poet Osip Mandelstam, who openly criticized Stalin (Fraser \& Yasnitsky, 2015; Krementsov, 1997).

Although we do not know Leontiev's exact work situation between 1936-7, Yasnitsky (2009) comments that in 1939 Leontiev and Luria were given leadership positions at research and education institutions in Moscow. This does not contradict reports by the other biographers. For Yasnitsky, that year they had already established new connections within the Party, without which it would have been impossible to thrive in the sciences.

\section{SOVIET POLICIES CRITICIZE “ENVIRONMENTAL” DETERMINISM}

The discussion about the environment and the way in which socialism reconfigured it was so delicate at that point that the pedologists' view of the interaction between heredity and the environment was criticized in the "On pedological distortions in the Narkompros" decree itself. As we will see below:

The $\mathrm{CC}$ of the $\mathrm{RCP}(\mathrm{b})$ considers that the theory and practice of so-called pedology are based on scientifically false and antiMarxist postulates. Related to these postulates is, above all, the main "law" of contemporary pedology - the "law" of fatalistic conditionality of children's fates due to biological and social factors, by the influence of heredity and the immutability of the environment in which they live. This deeply reactionary "law" stands in stark contradiction to Marxism and the whole practice of socialist construction, which has successfully re-educated people in the spirit of socialism and liquidated the preconceived ideas of capitalism in the economy and in people's consciousness. (Central Committee of the RCP(b), 2010, pp. 207-208, emphasis added)

Discussing the text of the decree, Leontiev (193?/2005c) reproduces this criticism of the idea of fatalistic determinism when starting out his critique of Vygotsky (in the larger context of his criticism of pedology). In various other aspects, the decree against pedology was the tip of the iceberg that signaled a new juncture: Darwinism - and within it, the controversy of genetics vs. environment - was no longer a scientific issue, but a political one.

The process of simplifying and transforming Darwinian ideas into part of official state ideology under the tutelage of Party philosophers led to the abandonment of efforts to locate 
Darwin's significance within the scope of Marxism in the 1920s (see Joravsky, 1961). This monopoly made it possible for a Stalinist "Darwin" to be dressed up as Lamarck: according to Krementsov (1997), Stalin's annotations dating from 1906 were already sympathetic to Lamarckism (see also Joravsky, 1959).

It is important to note that Engels himself had Lamarckian ideas. Stalin was merely responsible for selecting its most rigid and simplistic aspects, which were unfaithful to Lamarck's own ideas.

Decades after the Soviet controversies, Marxist biologists Levins \& Lewontin (1985) criticized the "Role of Work in the Transition from Anthropoid to Man" (Engels draft, 1876). For them, Engels emphasized the organism's activity in relation to its effects on the environment, but adopted a Lamarckian view of the direct inheritance of acquired traits. The authors argue for the necessary replacement of that direct causality by the action of natural selection, saying that it is imperative to emphasize the reciprocal human-nature interaction, rather than Engels' Lamarckian vices. Our research on Stalin (1938/1976) shows the dictator doing the opposite: he quotes Engels, but sacrifices these interactions for the sake of a purely "progressive" dialectic.

Amid the cultural revolution of 1923-30, Soviet pedology actually believed that the environment could change a person's biology (Minkova, 2012, p. 90). This persisted through to the elimination of pedology and also beyond, reaching its peak with the tragic Michurinization of Soviet biology by Lysenko and his group between 1948 and 1958 (Krementsov, 1997).

The background for this critique of biological and social "fatalism" included both the discussion of the social disadvantages faced by learners from the proletarian class, and from the growing unease regarding biological determinism as preached by eugenics, banished from the
USSR in 1930 (Krementsov, 2011, p. 62). Eugenics was increasingly associated with the racism of the Nazi state as World War II drew nearer - effectively beginning for Russia with the German attack on June 22, 1941 (Deutscher, 1970). In fact, the draconian Civil Code, the Anti-abortion Law, and the Stalin Constitution, all taking place in 1936, held individuals and social groups (especially families) responsible for working toward the construction of socialism. Under this strange form of individualism, the Soviet state moved away from the "fatalistic determinisms" of biology or society, setting up a sort of social surveillance fit only for totalitarian regimes.

Leontiev (193?/2005c, p. 9) minimized the value of comparisons based on empirical data regarding children's lives between pre- and post-revolutionary moments (or environments) in his "Study of the Environment ...", disqualifying some of the most interesting investigative schemes designed by the former Academy of Communist Education (where he worked until 1931). According to him, the scheme included questions about the economy of the district where the child lived, the socialist reconstruction companies, the educational characteristics of the workers in a certain district, as well as the school itself and its future prospects, thus deploying the child within an environment represented by a web of economic, institutional, cultural, and political relations. In our reading, such a scheme seems to be aligned with the construction of socialism from popular/ community bases, for which Stalin and his faction did not have the slightest interest. In the Decree, the Central Committee also anticipates Stalin's statement to the 18th Congress of the CPSU in 1939 (Krementsov, 1997, p.64) announcing that the basis of socialism had finally been reached: we also see it in the quotation that opened the present topic.

\section{A CONTRAST WITHVYGOTSKIAN PSYCHOLOGICAL MATERIALISM}

Some authors rightfully identify mechanicism and objectivism in Leontiev, although from distinct points of view (on the question of the personal sense, see GonzálezRey, 2007). In our analysis, by discussing the theme of the nature of consciousness and its relation to material reality, Leontiev (193?/2005c) establishes a constant in his work: the mixing up of ontological and epistemological problems, leading to a regression to the matter-consciousness duality (mind, spirit, psyche) when compared with Vygotsky. This unfolds in a "scaling," or hierarchization, of concepts the imposition of conceptual splits between matter and consciousness with a mechanistic and objectivist bent that leads to structural impacts on his theory.

As we have explained in other works devoted to the analysis of the psychological materialism present in
Vygotsky's "Historical Significance of Crisis in Psychology" (Toassa, 2015a, b, 2017), Vygotsky's Marxist naturalism resembles Spinoza's monism, where reality, nature, and substance are the same, and allowing us to identify the concepts of realism, naturalism and materialism (Vygotsky, 1991). For the author, materialism deals with everything that exists, including also conscious life - roughly, consciousness of self, of other subjects, and of the physical world elaborated on the thresholds of sensation and the selection of extracts of sensations in the form of a mental stream. In a brilliant (though unorthodox) interpretation of Lenin, he noted in psychology a confusion in the treatment of consciousness as a problem that is

1. Ontological: real and natural as a relationship between two objective processes based on a matter/energy 
interconnection between the body and the brain, which are parts and products of Nature; and

2. Epistemological: matter is what exists independently of consciousness and is reflected by it, including thought itself, as well as processes that occur in the body.

One of the consequences of this highlighted by Vygotsky is the acceptance of consciousness (empirical "I-Consciousness," or "mind") as an object of real study in its ontology, approaching the study of consciousness by consciousness itself from a subjective epistemological position. But the objectivity of this study is also possible if we study the objectified products of consciousness. Vygotsky diagnoses part of the dualistic crisis of psychology as arising from the confusion between the two problems; the root of the error of considering the subjective as non-material, disqualifying consciousness as a genuine scientific object - and psychology as a possible science.

We do not know if Leontiev was aware of Vygotsky (1927/1991) when he wrote this critique, but the confusion that is criticized in this superb text by Vygotsky is present in both "Study of the Environment ..." (Leontiev, 193?/2005c) and in the first part of the "Essay on the development of psychism" (1940/1978c). There, the possibility of an epistemological approach to consciousness from its ontological specificities dried up as a result of the split between consciousness (mind, spirit) and matter. The adoption of activity - not consciousness or personality - as the object of psychology is a consequence of this abstractly objectivistic inflection made by Leontiev (Toassa, 2016a).

In accusing Vygotsky of not promoting an adequate solution to the subject-object relationship, and breaking it up, Leontiev (193?/2005c) demands a solution to a problem he himself created with his regression towards dualism. We can observe this when he sees in Vygotsky a fault that is characteristic of pedology:

This error is, on the one hand, a failure to understand that something taken in the abstract is not an object of science, that "from bodies removed from motion, removed from any relation to others, nothing can be affirmed" (F. Engels. [...]), that the properties of things are discovered only through their essential interrelations [...] from the outset, pedology, from the starting point of its investigations, removed true unity: the unity of subject and object, the personality of a person and their human reality. Through abstraction, the child has been removed from the actual process of life, from the interaction that is its real existence. (Leontiev, 193?/2005c, pp. 10-11)

Leontiev et al. (2005) hit the mark when observing that A.N.'s criticism presents ideas that the Kharkov group had already established well. Toassa (2016a) describes how Vygotsky was criticized when answering that behind consciousness lies "life," i.e., affections. In opposition to this, A.N. and the Kharkovites desired that behind consciousness there should be "activity" - as a direct representative of materiality. We did not identify a similar idea among Vygotsky's Stalinist critics, although their demand for a "materialist" critique of Vygotsky was known to Leontiev.

In the perspective of the Marxist Anna Stetsenko, the study of the connection between "consciousness" and "activity" by Leontiev maintained the belief in the existence of two different realities, which we interpret as the elaboration of a "mechanical" rather than a "dialectic" analysis:

This is what has actually happened: the unity of consciousness and activity began to be regarded as the unity of different entities, in the sense of unity of origin and structure, and even a unity in interdependence, but not as genuine unity, a "unity in difference". (Stetsenko, 1995, pp .62-63)

Emphasizing the importance of material relations, obligatory after the Great Break, Leontiev moved toward a joining of the ontological dualism between matter and consciousness, or rather between activity and consciousness. This brings with it epistemological consequences - for the notion of the ontological priority of practical activity in relation to consciousness "blocks" the construction of his understanding of the multiplicity of experiences and its necessary overlap with every human activity, in the Vygotskian mode. Thus, the notion of activity acquired an imprecise theoretical role, serving both to describe and to explain reality (Lazarev, 2004; Zinchenko, 2004), a defect that would prove to be foundational, leading to circular thinking that is quite deficient as a dialectical psychological theory. Instead of spirals, Leontiev describes circles.

\section{CONCEPTUAL SCALING AND THE BREAK BETWEEN MATTER AND CONSCIOUSNESS}

What we call "scaling of concepts" is an unfolding of Leontiev's dualism: a theoretical hierarchy that invariably promotes "material relations" between subjects and things, as well as object activity, to the "first place" of psychic life, to the causal plane of the development of reflection (as well as consciousness/personality). This seriously damages the understanding of the unity of mind and body and its multideterminity, although it also - in a discursive 
contradiction of the Stalinist ideology - affirms the unity between thought and activity.

Serving as a model of "conceptual scaling" for all of society, the force of law disseminated Stalin's work across Soviet science, using a repetitive style marked by nondialectic affirmations about the primacy of the material over the spiritual:

[...] the ties between science and practical activity, between theory and practice, its unity, should be the guiding star of the party of the proletariat.

Furthermore, if nature - that is, the material world - is primary, and consciousness - thought - is secondary, derivative; if the material world represents objective reality existing independently of the consciousness of men, while consciousness is a reflection of this objective reality, it follows that the material life of society, its being, is also primary, and its spiritual life is secondary, derived. [...]

Therefore, the source for the formation of the spiritual life of society, the origin of social ideas, social theories, political perspectives and political institutions, should not be sought in ideas, theories, perspectives and political institutions in themselves, but in the conditions of the material life of society, in the social being, of which these ideas, theories, perspectives, etc., are the reflection. (Stálin, 1938/1976, p. 849)

The strength and vitality of Marxism-Leninism lies in the fact that it bases its practical activities on the needs of the development of the material activity of society, and is never divorced from the real life of society. (Stalin, 1938/1976, p. 851)

Hammering on the primacy of material production "in the last instance," it becomes practically the "only instance" thanks to Soviet productivism. The suffocation of the intellectual production that took place in it has also played an important role. This scaling, steeped in the cunning discursive practices of the time, may prove to be extremely confusing to Latin American readers. Although it retains several words from Vygotsky's vocabulary - many of them common to Russian-language psychology at the time - Leontiev constructs a theoretical framework that sometimes completely drains them of the descriptive and explanatory potential they had under the psychological materialism framework of their former leader.

That is the case of the concepts of experience and meaning, which Leontiev considers to have been introduced into Soviet psychology by Vygotsky. Closing out the "Study of the Environment...," he writes

These concepts should be introduced into psychology, but they should be introduced in an absolutely different way than the way Vygotsky did it. Every concrete proposition, every fact upon which it is based, must first be critically refined and interpreted from the point of view of a materialistic psychological theory. (Leontiev, 193?/2005c, p. 27)

When dealing with the application of spoken words to new objects, Leontiev (193?/2005c) observes that their use results from the interaction of two factors: (1) the child's actual relation to things; (2) the meaning - a purely linguistic phenomenon involving the movement of the word through a series of things/objects. In another act of conceptual scaling, he states: "What is most important in this interaction is, of course, the first fact. This is an indisputable principle of psychology that can be definitively proven experimentally" (p.24, our translation).

In personal notes dating back to 1934, Leontiev's habit of dividing up the "material and spiritual" is criticized by Vygotsky himself. This is our interpretation based on the following considerations made by Vygotsky who, as Zavershneva says, in criticizing Leontiev's thinking that sustains a monistic reading of the relation between (practical) activity and thought:

the role of [thinking] in activity consists in introducing new dynamic possibilities for activity. To say that thought is impaired is tantamount to saying that subtle and complex dynamic processes in activity are damaged. (Vygotsky, cited by Zavershneva, 2010, p. 83)

Stalin was concerned with guaranteeing the social division of labor into practical and intellectual activity, contributing to the construction of an ideology of unity between workers of both spheres in order to promote the extremely difficult cooperation of both groups with the goals of the Five Year Plans, begun in 1929. However, the passion for Taylorism and the "revolution from above" in industry and agriculture that marked that era contributed to the construction of a rudimentary materialism, characterized by the objectivist and authoritarian primacy of practical activity.

This is the rationale for both the conceptual divisions (and the objectivism/mechanicism noted in them) and for the discursive obscurity of poor Leontiev, which he himself admits to (Toassa, 2016a). In our interpretation, by seeking to defend himself against future sanctions arising from abrupt changes in politics it was not uncommon for the author to slip into vacuous and self-contradictory statements (traits also noted by Stetsenko, 1995). Let us look at excerpts from the first part of the "Essay on the Development of Psychism" (dated 1940 by Zaporozhets, 1981) - which we compared with the Russian original, without noting differences of meaning:

We thus see that the development of pyschism is determined by the need of animals to adapt to the environment, and that the psychic reflex is the function of corresponding organs formed in the process of adaptation. (Leontiev, 1940/1978c, p. 59) 
In response to the transformation of the conditions of existence, animal activity changes its structure - or, in other words, its "anatomy." [...]

Thus, the development of the forms of psychic reflex seem to be placed one degree lower in relation to the structure of animal activity, so that there will never be a correspondence between them. (Leontiev, 1940/1978c, p. 60, emphasis added)

Readers may struggle to imagine how the psychic reflex can be a function of the organs that correspond to it without being a function of the activity that they perform. These statements lend themselves to the defense of the absolute power of the conditions of existence (again, quite to the satisfaction of Stalinism) in a certain objectivism that does not give due space to the important Engelsian notion of interaction. In this Lamarckism practiced by Leontiev, the conditions of existence modify the activity, and that, in turn, modifies animal anatomy. As we have already stated, the interrelationships that occur in the natural world (thanks to the legacy Engels provided to Soviet science) do not appear as an effective monistic materialism focused on the unity of consciousness-activity in the evolution of life and of changes in culture.

The ideas in the passage just transcribed are similar to the article Psikhika, written by Leontiev for the "Great Soviet Encyclopedia." In that work as well, the notion of a "lack of correspondence between reflection and material conditions" arises from a crude distinction between form and content, which is also present throughout the first part of the "Essay on the development of psychism." We find its probable source in a text dated the same year:

And in life, first there were the changes of external and material conditions, and then of people's thinking, their world-view... in one way or another, because of its content, but never fully corresponding to this content and, therefore, new content is often temporarily "forced" to enter into the old form, and this causes a conflict between them. (Stalin, in the book: Beria L., On the history of Bolshevik organizations in Caucasus, cited by Leontiev, 1940, our translation, emphasis added)

To Leontiev, one should study personality as a vehicle for a set of internal properties and instincts. By observing that the relation of the subject to the object of the environment passes through activity (of its content and level of development in a certain social structure), he deconstructs the Vygotskian notion that experience represents the very unity of consciousness/personality structured along two poles, subject and object. In these poles, the ontogenesis (child development) occurs through the existence of other subjects: "in experience, we always deal with the indivisible union of the particularities of the personality and the peculiarities of the situation represented in experience" (Vygotsky, 1935/2010, p. 686, emphasis in original).

Leontiev separates the monist simultaneity posited by Vygotsky. The latter gives precedence to the emergence of socio-material production mediated by people in relation to language and the capacity to experience the world. In contrast, it is perfectly clear that Vygotsky's pedology thought that we experience the world starting at our birth (Toassa, 2011). But Leontiev argues that children begin their development through material activity in relation to material reality. Before establishing contact with the objects of their reality in some sort of "spiritual" theoretical relationship, the child must eat, breathe, and direct other vital functions, acting as a completely material and practical being. The example that follows could serve as a negative illustration of a Kantian ethic founded on the conversion of the other subject into the finality of one's own action - or even of the humanization of life by socialism:

When a mother gives a child what she has asked for, in this act there is an essentially dual relationship: the child not only performs an action in relation to a given object through her mother, but the relationship with the mother now occurs through a relationship with that object. Put another way, this specific relationship between the child and another person occurs initially only to the extent that it is a precondition for realizing her relationship to an object that she needs. (Leontiev, 193?/2005c, p. 23, emphasis added)

At the cost of the complete de-subjectivation of the maternal figure, Leontiev buys into a caricature of materialism, fully attuned to the deconstruction of the clinical psychology/pedology, as sciences focused on the careful observation of interactions between adult and child. As a result, he distances himself from the simplest daily practice of raising babies, whose physical and mental health demands tenderness, food, hygiene, and interaction with caregivers.

To continue within the author's own theoretical framework, it is legitimate to recognize that in his defense of "practical activity" there is still vacuity and lack of practical experience, with no theoretical expression of the concrete analysis of the experience of caregivers as a form of work. There was a lot of criticism on the vagueness and lack of empirical material in Leontiev's theory of activity, both before and after the end of the Soviet Union (see Bakhurst, 2009, Bozhovich cited by Yasnitsky \& Ferrari, 2008b; Lazarev, 2004; Zinchenko, 2004).

We should also mention the observation made by Brushlinskii (2004), for whom Leontiev's and Galperin theory of internalization - from the 1950s onwards - took external causes (at least during the early stages of ontogenesis) as a direct determination of psychic development, and not "through internal conditions" (p. 73). This assumption marked the objectivism of Leontiev's theory of activity, in contrast to Rubinstein's theory of activity. In Leontiev's theory, he ignores even bodily sensations arising from the basic needs of the newborn (such as food, the most basic of all for the maintenance of our material existence), one of the irreplaceable facets of the formation of consciousness/ personality for Vygotsky. 
In the "Study of the Environment...", the ontological precedence of material needs and practical activity in relation to "spiritual" ones likewise justifies their epistemological precedence in phylo- and ontogenesis. This is part of the phenomenon which we defined as the "conceptual scaling" of his theory.

Politically, the ideas present in the text under analysis seem to us to be effective in concretizing Leontiev's departure from Vygotskian pedology, without the author rectifying this position a posteriori - before or after the Thaw that began following Stalin's death in 1956. It is also noteworthy that Leontiev had worked as an experimental child psychologist and an author of general psychology, but we have no news of his being a pedologist. One sign of this is that the root педолог- (pedolog-, common to the noun pedology and associated adjectives) does not appear in the list of titles of his works (compiled by D.A. Leontiev, 2004).

\section{FINAL CONSIDERATIONS}

It would be hard to find an academic who better represents the contradictory effect that Stalinist authoritarianism had on psychology than Leontiev. Because he did not actively participate in the campaign to bolshevize this science during the 1930s, the fact is that we cannot simply consider him as a "militant Stalinist" - a term that acquires a pejorative connotation, focused merely on the biographical analysis of the author's relationship to a state ideology. Our series of articles sought to transcend this level of problematization by elucidating the workings of the system of Stalinist scientific production and their impacts on the life of a researcher who showed himself to be particularly skilled in dominating the discursive practices necessary to survive under Stalinist authoritarianism, which sought a unified, "pure and genuine" Marxism.

The price paid in this process of Leontiev's adaptation to Stalinist totalitarianism was not an advance but a regression with respect to Vygotskian psychological materialism, in addition to constructing a vague, objectivist, mechanistic and sometimes self-contradictory theoretical structure endowed with significant deficiencies that formed the basis of a contemporary Marxist psychology (and education). Responding to Stalin's own writings in the 1930s, Leontiev promoted the practice of dividing matter (activity) and consciousness (mind, psyche), returning to the dualist confusion that had been criticized by Vygotsky (1991). This occurred at the same time that he was developing the theory of activity, which according to Leontiev et al. (2005) was already structured in 1940 (see also Leontiev, 1940/2005a, b).

We can also relate these theoretical limitations to the fact that Stalin and his followers (1929-53) undertook an abrupt objectivist inflection in the direction of practical activity, while condemning all kinds of effective public analysis of the concrete life of Soviet peoples. Roughly speaking, this can be perceived both in the condemnation by the Party-State of pedology and Luria's expeditions to Uzbekistan. As a result, the Secretary-General and his minions succeeded in forging - within many sciences, including psychology - a paradoxical "anti-empirical objectivism," in which, with the stroke of a pen, clinical practices were shattered (with the exception, perhaps, of defectology). Education sciences often reproduced the demands of the Party and shied away from working towards a socialism of solidarity, controlled by the workers themselves and not by Party bureaucrats.

The reduction of Vigotsky's psychology project, with all its richness, depth, and breadth, was dramatic. For these reasons, we think that if the fundamental task of a Marxist psychology is to contribute to the emancipation of the proletariat, it will be difficult to do so through Leontiev's much too narrow associations with Vygotsky. Leontiev has researched mostly at a time when, to paraphrase Akhmatova, the Soviets were strangers in their own land.

\section{REFERENCES}

Akhmatova, A. (2009). Antologia poética. Porto Alegre, RS: L\&PM. Bakhurst, D. (2009). Reflections on activity theory. Educational Review, 61(2), 197-210. doi: 10.1080/00131910902846916

Bauer, R. A. (1952). The new man in soviet psychology. Boston: Harvard University Press.

Brushlinskii, A. V. (2004). The Activity Approach and Psychology. Journal of Russian and East European Psychology, 42(2), 69-81.

Comitê Central do Partido Comunista da Rússia (PCRb). (2011). Sobre as deturpações pedológicas no sistema dos Narcompros. Decreto de 4 de julho de 1936. In Z. R. Prestes (Ed.), Quando não é a mesma coisa: Análise de traduções de Lev Semionovitch Vigotski no Brasil: Repercussões no campo educacional (Tese de Doutorado). Universidade de Brasília, Brasília, DF, Brasil.
Deutscher, I. (1970). Stálin: A história de uma tirania (Vol. 2). Rio de Janeiro: Civilização Brasileira.

Duarte, N. (1996). A escola de Vigotski e a educação escolar: Algumas hipóteses para uma leitura pedagógica da psicologia histórico-cultural. Psicologia USP, 7(1-2), 17-50. doi: 10.1590/ S1678-51771996000100002

Duarte, N. (2001). Vigotski e o" aprender a aprender": Crítica às apropriações neoliberais e pós-modernas da teoria vigotskiana. Campinas, SP: Autores Associados.

Fraser, J., \& Yasnitsky, A. (2015). Deconstructing Vygotsky's victimization narrative: A re-examination of the "Stalinist suppression" of Vygotskian theory. History of the Human Sciences, 28(2), 128-153. 
Golder, M. (2004). Leontiev e a psicologia histórico-cultural: Um homem em seu tempo. São Paulo: Grupo de Estudos e Pesquisa sobre Atividade Pedagógica/Xamã.

González-Rey, F. (2007). As categorias de sentido, sentido pessoal e sentido subjetivo: Sua evolução e diferenciação na teoria histórico-cultural. Psicologia da Educação, 24, 155-179.

Joravsky, D. (1961). Soviet Marxism and Natural Science: 1917 1932. Abingdon: Routledge.

Joravsky, D. (1989). Russian psychology: A critical history. New Jersey: Blackwell.

Krementsov, N. (1997). Stalinist science. Princeton, NJ: Princeton University Press.

Krementsov, N. (2011). From 'Beastly Philosophy'to Medical Genetics: Eugenics in Russia and the Soviet Union. Annals of Science, 68(1), 61-92.

Lazarev, V. S. (2004). The crisis of" the activity approach" in psychology and possible ways to overcome it. Journal of Russian and East European Psychology, 42(3), 35-58

Leontiev, A. A (2005). The Life and Creative Path of A.N. Leontiev. Journal of Russian and East European Psychology, 43(3), 8-69. doi: 10.1080/10610405.2005.11059249

Leontiev, A. A., Leontiev, D. A., \& Sokolova, E. E. (2005). Primeiros trabalhos de A.N. Leontiev e o caminho para a psicologia da atividade [Rannie raboti A.N. Leontieva i evo put $\mathrm{k}$ psikhologii deiatelnosti]. In A. N. Leontiev (Ed.), Stanovlenie psikhologuii deiatelnosti: Rannie raboti (pp. 8-27). Moscou: Smisl.

Leontiev, A. N. (1940). Psique [Psikhika]. In O. Y. Schmidt (Ed.), Bol'shaya sovetskaya entsiklopediya (Vol. 47, pp. 497-501). Moscow: Sovetskaya.entsiklopediya.

Leontiev, A. (1978a). Actividad, consciencia y personalidad. Buenos Aires: Ciencias del Hombre.

Leontiev, A. N. (1978b). O desenvolvimento do psiquismo. Lisboa: Horizonte Universitário.

Leontiev, A. N. (1978c). O desenvolvimento do psiquismo animal. In $O$ desenvolvimento do psiquismo (pp. 19-68). Lisboa: Horizonte Universitário. (Original de 1940)

Leontiev, A. N. (2005a). The fundamental processes of mental life. Journal of Russian and East European Psychology, 43(4), 72-75. (Original de 1940)

Leontiev, A. N. (2005b). The genesis of activity. Journal of Russian and East European Psychology, 43(4), 58-71. (Original de 1940)

Leontiev, A. N. (2005c). Study of the environment in the pedological works of LS Vygotsky: A critical study. Journal of Russian and East European Psychology, 43(4), 8-28. (Original de 193?)

Leontiev, D. A. (2004). Lista de trabalhos publicados de A. $N$. Leontiev [Spisok petchatnikh rabot A.N. Leontieva]. Recuperado de http://anleontiev.smysl.ru/sp_publ.htm.

Levins, R., \& Lewontin, R. (1985). The dialectical biologist. Harvard University Press.

Martins, J. B. (2013a). Apontamentos sobre a relação Vigotski e Leontiev: A troika, ela existiu? PsyAnima, Dubna Psychological Journal, 1, 71-83.

Martins, J. B. (2013b). Da relação Vigotski e Leontiev Alguns apontamentos a respeito da história da psicologia soviética. Revista Interamericana de Psicología, 47(1), 43-52.

Minkova, E. (2012). Pedology as a complex science devoted to the study of children in russia: The history of its origin and elimination. Psychological Thought, 5(2), 83-98.

Netto, J. P. (1982). Introdução. In J. V. Stálin, Stálin: Politica (pp. 9-36). São Paulo: Ática.

Rubinštejn, S. L. (1987). Problems of psychology in the works of Karl Marx. Studies in Soviet Thought, 33(2), 111-130 (Original de 1934) doi: 10.1007/BF01151778
Rudneva, E. I. (2000). Vygotsky's pedological distortions. Journal of Russian and East European Psychology, 38(6), 75-94 (Original de 1937)

Stalin, J. (1976). Dialectical and historical materialism. In Problems of Leninism (pp. 835-873. Pequim: Foreign Languages Press.

Stetsenko, A. P. (1995). The role of the principle of objectrelatedness in the theory of activity. Journal of Russian and East European Psychology, 33(6), 54-69.

Toassa, G. (2011) Emoções e vivências em Vigotski. Campinas, SP: Papirus.

Toassa, G. (2015a). Há um Materialismo Vygotskyano? Preocupações ontológicas e epistemológicas para uma psicologia marxista contemporânea (Parte I). Dubna Psychological Journal, 1, $58-68$.

Toassa, G. (2015b). Há um Materialismo Vygotskyano? Preocupações ontológicas e epistemológicas para uma psicologia marxista contemporânea (Parte II). Dubna Psychological Journal, 3 , 66-80.

Toassa, G. (2016a). "Atrás da consciência, está a vida": O afastamento teórico Leontiev-Vigotski na dinâmica dos círculos vigotskianos. Educação \& Sociedade, 37(135), 445-462. https://doi.org/10.1590/ES0101-73302016144457

Toassa, G. (2016b). Nem tudo que reluz é Marx: Críticas stalinistas a Vigotski no âmbito da ciência soviética. Psicologia USP, 27(3), 553-563. https://doi.org/10.1590/0103-656420140138

Toassa, G. (2017). Criando uma psicologia materialista - Fontes e influência de Espinosa nos trabalhos de Vigotski. In A. A. S. de Oliveira (Ed.), Psicologia sócio-histórica e o contexto de desigualdade psicossocial: teorias, método e pesquisas (pp. 13-26). Maceió, AL: EDUFAL.

Vygotski, L.S. (1991) El significado histórico de la crisis de la psicología. Una investigación metodológica. In Obras escogidas (Vol. 1, pp. 259-407). Madrid: Visor.

Vigotski, L.S. (2010). Quarta aula: A questão do meio na pedologia. Psicologia USP, 21(4), 681-701. (Original de 1935)

Vygodskaya, G. L., \& Lifanova, T. M. (1999). Through a daughter's eyes (Cont.). Journal of Russian and East European Psychology, 37(5), 3-27.

Yasnitsky, A., \& Ferrari, M. (2008a). From Vygotsky to Vygotskian psychology: Introduction to the history of the Kharkov school. Journal of the History of the Behavioral Sciences, 44(2), 119-145. doi: 10.1002/jhbs.20303.

Yasnitsky, A., \& Ferrari, M. (2008b). Rethinking the early history of post-Vygotskian psychology: The case of the Kharkov school. History of Psychology, 11(2), 101-121. doi: 10.1037/1093-4510.11.2.101

Yasnitsky, A. (2009) Vygotsky Circle during the decade of 19311941: Toward an integrative science of mind, brain, and education (Tese de doutorado). University of Toronto, Toronto, Canada.

Yasnitsky, A. (2012). Revisionist revolution in Vygotskian science: Toward Cultural-Historical Gestalt Psychology. Journal of Russian and East European Psychology, 50(4), 3-15. doi: 10.2753/RPO1061-0405500400

Zaporozhets, A. V. (1981). Notas [Primetchania]. In A.N. Leontiev. Problemi Razvitia Psikhiki (4 ed. pp. 558-564). Moscou: Editora da Universidade de Moscou.

Zavershneva, E. I. (2010). The Vygotsky family archive: New findings. Journal of Russian and East European Psychology, 48(1), 34-60.

Zinchenko, V. P. (2004). The Psychological Theory of Activity: "Remembrances of the Future". Journal of Russian and East European Psychology, 42(2), 30-68. 